\title{
Relation between quality of cervical smears and probability of abnormal results
}

\author{
Frank Buntinx, J André Knottnerus, \\ Harry F J M Crebolder, Gerard G M Essed, \\ Hubert Schouten
}

\section{Department of General Practice, State University of Limburg, PO Box 616 6200 MD Maastricht, Netherlands \\ Frank Buntinx, general practitioner researcher \\ J André Knottnerus, professor \\ Harry F J M Crebolder, professor}

\section{Department of}

Gynaecology

Gerard G M Essed, professor

\section{Department of Medical}

Statistics

Hubert Schouten, associate professor

Correspondence to:

Dr Buntinx.

BMF 1992;304:1224
Cytological screening of the cervix is widely used for early diagnosis of cervical dysplasia. However, high rates of false negative and false positive results have been reported. One of the causes of the inaccuracy may be inadequate quality of smears. We examined the relation between quality of the smear and the probability of finding a positive result.

\section{Methods and results}

We studied all 17664 smears obtained by 179 general practitioners and gynaecologists over 11 months. We included both smears taken for screening and those taken for specific indications. The quality of all smears was judged according to five criteria. In addition, the presence and type of abnormal cells, the age of the patient, and a code for the laboratory assistant who examined the slide were recorded. A smear was considered good if $(a)$ endocervical cells or squamous metaplasia, or both, were present; $(b)$ the cell was fixed so that the contours of cellular structures were clear, stainability was good, and the slide was neat; (c) sufficient epithelial cells were present; $(d)$ no or sporadic poorly interpretable clumps of cells were found; and $(e)$ there were no signs of inflammation sufficient to hinder assessment. A smear was considered abnormal when at least mild dysplasia was found ( $\geqslant$ Papanicolaou class IIIa).

The association between each quality criterion and the presence of abnormal cells was tested by a $\chi^{2}$ test with Yates's correction. Subsequently, the influence of the quality criteria on the detection of abnormal cells was investigated by stepwise logistic regression. The presence of abnormal cells was the dependent variable and the age of the patient ( $>40$ or $\leqslant 40$ years), the code for the screening technician, and the quality indicators

Number (percentage) of abnormal smears with a good or poor assessment

\begin{tabular}{|c|c|c|c|c|c|c|}
\hline & \multicolumn{2}{|c|}{ Good quality } & \multicolumn{2}{|c|}{ Poor quality } & \multirow[b]{2}{*}{ Odds ratio } & \multirow[b]{2}{*}{ p Value ${ }^{\star}$} \\
\hline & $\begin{array}{l}\text { No of } \\
\text { smears }\end{array}$ & $\begin{array}{c}\text { No }(\%) \\
\text { abnormal }\end{array}$ & $\begin{array}{c}\text { No of } \\
\text { smears }\end{array}$ & $\begin{array}{c}\text { No (\%) } \\
\text { abnormal }\end{array}$ & & \\
\hline General quality & 15475 & $143(0.9)$ & 2189 & $25(1 \cdot 1)$ & 0.82 & 0.39 \\
\hline Endocervical cells & 15674 & $155(1.0)$ & 1990 & $13(0 \cdot 7)$ & 1.43 & $0 \cdot 18$ \\
\hline Fixation & 17470 & $156(0.9)$ & 194 & $12(6 \cdot 2)$ & 0.15 & 0.00 \\
\hline No of cells & 17597 & $168(1.0)$ & 67 & 0 & & $0 \cdot 86$ \\
\hline Clumps of cells & 17630 & $168(1.0)$ & 34 & 0 & & 1.00 \\
\hline Infection & 17624 & $168(1.0)$ & 40 & 0 & & 1.00 \\
\hline
\end{tabular}

${ }^{\star B y} \chi^{2}$ test. were the independent variables. Interaction was controlled for. We started from a complete, hierarchically constructed model.

Of the 17644 smears, 168 gave abnormal results $(0.95 \%)$. We found no relation between four quality indicators and presence of abnormal cells, but a significant inverse relation was found with the quality of fixation (table). Inadequate fixation resulted in an increased number of abnormal cells (relative risk $=7 \cdot 14$ ). Further analysis showed that this relation was not attributable to one or a few doctors fixing smears poorly.

The final regression equation comprised the independent variables year of birth, presence of endocervical cells, and adequacy of fixation. The model fitted our data well (Hosmer-Lemeshow $p=0.556$ ). After adjusting for age of patient, the screening assistant, and quality criteria, the odds ratio for year of birth was 1.62 (95\% confidence interval $1 \cdot 15$ to $2 \cdot 26$ ), for presence of endocervical cells was $1.56(0.86$ to $2 \cdot 82)$, and for adequacy of fixation was $0.14(0.07$ to $0 \cdot 27$ ).

\section{Comment}

Our observation that the number of smears with abnormal cells is increased seven times when slides are fixed inadequately, even after correction for confounding variables, suggests strongly that inadequate fixation may lead to large numbers of false positive results. Smears dry quickly in the air, resulting in cellular artefacts, poor intensity of staining, and masking of abnormal cells. ${ }^{2}$ As well as masking abnormal cells the artefacts could imitate abnorma cells, possibly partly explaining the high rate of false positive results found in cervical screening.

Our analysis confirms that the year of birth and the presence of endocervical cells are positively associated with detection of abnormal cells, ${ }^{3-5}$ although for the endocervical cells the association was not significant. The laboratory assistant, the presence of clumps of cells, signs of infection, and number of cells in the smear seemed to have no significant effect on the presence of abnormal cells.

We thank the staff of the Central Laboratory, Antwerp Praeventiefonds; and G Fraussen, T Seegers, I Siegelaer, and D Wahrndorf.

1 Zuna RE. The PAP smear revisited: controversies and recent developments. Postgrad Med 1984;76:36-46.

2 Steiner $C$. Cervical cancer screening from the public health perspective. Acta Cytol 1989;33:471-4.

3 Buntinx F, Boon ME, Beck S, Knottnerus JA, Essed GGM. Comparison of Cytobrush sampling, spatula sampling and combined Cytobrush-spatula sampling of the uterine cervix. Acta Cytol 1991;35:64-8.

4 Mitchell H, Medley G. Longitudinal study of women with negative cervical smears according to endocervical status. Lancet 1991;338:265-7.

5 Vooijs GP. Significance of cellular composition of smears for the reliability of cytological diagnosis. In: Goerttler K, Fiechter G, Witte S, eds. New frontiers in cytology. Berlin: Springer-Verlag, 1988:412-20. 